\title{
Cost Reduction through Relocation, or the Construction of Myths in Discourse
}

\author{
GENY PIOTTI \\ Max Planck Institute for the Study of Societies, Cologne
}

The findings of recent studies into relocation by German companies are puzzling: companies relocate because they are willing to cut costs, but entrepreneurs and managers seem to have failed to predict further and sometimes fatal costs associated with relocation. This paper sheds light on why relocation has become a general trend among German companies, despite those inefficiencies and costs. It points to the role of the discourse in creating the myth of relocation as a strategy to reduce costs. Discourse can in fact help to diffuse ideas independently of their empirical truth and give voice to influential actors who are able to induce isomorphic processes. In order to give an account of why companies' decisions to relocate have become so popular in Germany, regardless of their economic soundness, the paper draws on an analysis of German newspapers and business press that were published between January 1990 and July 2005.

KEY WORDS International relocation, Public discourse, Diffusion of ideas and isomorphism, Myth, German firms, Eastern Europe, Asia

\section{Introduction}

The findings of recent studies on relocation by German companies are puzzling. Relocation has certainly become a feasible and desired option for companies: ${ }^{1}$ several surveys point to important relocation tendencies among German firms (DIHK 2003, 2006; Kinkel et al. 2004). According to these surveys, 25 per cent of German manufacturing companies in 2003 had relocated during the previous two years. In 2004, about one-fourth of the companies surveyed were planning to relocate at least part of their production activities in the next three vears. Between 2004 and 2006, 19 per cent of companies in Germany engaged in some sort of relocation, especially to Eastern Europe and Asia (Kinkel \& Maloca 2008; Statistisches Bundesamt 2008).

International relocation of production has not only become important quantitatively, its qualitative nature is also changing: relocation is no longer the exclusive prerogative of big manufacturing companies, as it was in the past. Small and medium-sized enterprises (SMEs) are in fact increasingly investing in new production plants, as well as research and development (R\&D) activities in low-wage countries (Kinkel et al. 2004). ${ }^{2}$ Services are also becoming increasingly decentralised (European Commission 2003: OECD 2004).

E-mail address: gp@mpifg.de

(C) 2009 the Editors and W. S. Maney \& Son Ltd

DOI: $10.1179 / 102452909 \times 451396$ 
The literature on globalisation in general and relocation in particular indicates some good reasons for internationalisation. The issue of costs seems to be one of the dominant rationales behind relocation (Berger 2006), along with one of expanding markets. ${ }^{3}$ Environmental conditions have favoured global expansion of enterprises by enhancing opportunities and strengthening the need for internationalisation. The diffusion of new technologies, for example, facilitates communication and economic exchange by reducing the costs for companies engaged in international exchanges and transnational company management (Castells 2000; Dunning 1993). What's more, the processes of liberalisation in developing countries have helped to attract foreign investment because of their fiscal advantages and lower labour costs (Berger 2006) and have made relocation more convenient for companies than trading from the home country (Faini 2004). Finally, the institutional asset of the home country can facilitate or even set off relocation processes. On the one hand, the advantages of reducing costs are supposed to be more relevant for entrepreneurs situated in liberal economies, as firms are more dependent on market coordination (Berger 1996, 2006; Hall \& Soskice 2001). On the other hand, companies operating in coordinated market economies, characterised by higher labour and nonwage labour costs, could also see the attraction of cutting labour costs to become more competitive and put pressure on governments to carry out reforms (Crouch \& Streeck 1997).

Although relocation seems to be becoming increasingly popular among German companies, and the literature underlines good reasons for carrying it out, especially with reference to cost issues, these processes are not free from contradictions (Hirsch-Kreinsen \& Schulte 2000; Kinkel et al. 2004; Schulte 2002). Companies can decide to relocate because they are willing to cut costs; however, this strategy can itself produce costs that the entrepreneurs and managers can fail to predict. Estimation made on the basis of the survey of relocating firms shows that, of the firms that relocated outside of Germany between 2001 and 2003 and between 2004 and 2006, about one-fifth of them came back to Germany during the same period of time (Kinkel \& Maloca 2008; Kinkel et al. 2004). Companies that came back between 2004 and 2006 did so particularly from the new EU member states in Eastern Europe, which were also the most popular destinations for relocation in the same period of time. ${ }^{4}$ And these closures could be only the tip of the iceberg. There may be companies that decided not to return to Germany despite production inefficiencies and a lack of profitability. This happens, for instance, where companies invest in regions that, at least at first glance, offer huge potential market share in addition to low labour costs. A recent survey on German production firms in China - the second most important target destination for relocations by German companies - shows that 30 per cent of the companies with their own production plant needed between two and four years to reach break-even point; for another 20 per cent, it took at least four years of market presence in China to break even, which is a heavy burden especially for SMEs. A further 20 per cent of German production firms in China are making no profit at all. Companies that returned to Germany during the years studied were not included in the sample (GIC \& EAC 2008). A study conducted by Deutsche Bank shows that the incremental capital-output ratio (ICOR), i.e. the marginal amount of investment capital necessary for an entity to generate the next unit of production, has been constantly increasing in China since the middle of the 1990s; this underlines the decreasing efficiency associated with investments in China despite the increasing number of relocations there (Deutsche Bank 2004).

Why has relocation become a general trend, despite inefficiency and costs? How could it happen in a country like Germany, where the status of 'made in Germany' and the use of 
Germany as a business location have generally been seen as keys to German economic success?

Some recent studies point to a sort of discrepancy between the expectations and the actual experiences of German entrepreneurs and managers regarding relocation. This derives from a general overestimation of the opportunity to reduce production costs and from an underestimation of the strengths of the German model and the extent to which these can be found in the new context (Hardock 2000; Hirsch-Kreinsen \& Schulte 2000; Kinkel et al. 2004; Meck 2007). It is not clear, however, how these expectations are generated: what leads entrepreneurs to overestimate the opportunities to reduce production costs, to underestimate the advantages in the home country and, ultimately, to relocate?

The present paper should contribute to the general debate by focusing on the sources of actors' changes at the cultural-cognitive level and the mechanisms of diffusion of organisational strategies. This implies that we clarify how myths are constructed, i.e. how interests are formed, how 'good reasons' for new organisation strategies are socially constructed and organisational strategies become widespread. The theoretical element of the argument combines the tradition of thoughts about ideas and interests in political science and political economy (Blyth 2002; Campbell 1998, 2004; Goldstein \& Keohane 1993; Hall 1993) with the neo-institutional theory of organisations (DiMaggio \& Powell 1983; Fligstein 2001; Meyer \& Rowan 1991) and discourse. The empirical element is concentrated on the role of the public discourse on relocation and the role of the main actors in the discourse itself in encouraging companies to relocate.

When there is uncertainty about the general functioning of the economy (Beckert 1996, 1999, 2002; Culpepper 2003; Iida 1993), public discourse can function as an arena in which ideas and interests are constructed and diffused and possible options of behaviour are created. Discourse contributes to their definition by selecting, amplifying, legitimising and delegitimising arguments and causal relationships (Schmidt 2003) between the functioning of the market and individual behaviour. It can frame interests and strategies of firms by means of new or already existing ideas about how the economy works and how actors should behave in order to cope with its challenges. The public discourse is a political arena where dominant key actors have voice, social conflicts are created or simply reproduced and powerful actors can provide legitimation for their action and more easily induce other actors to behave in the same way. By diffusing information about the behaviour of other actors, discourse fosters imitation processes. As much as discourse can favour the creation of myths, however, it can also lead to the diffusion of inefficient practices. In fact, since there are often competing ideas on how the economy functions and how problems should be solved, the presence of dominant ideas in the public discourse can lead to unilateral views that are unquestionably accepted by economic actors, the side effects of which can be underestimated.

In order to give an account of why the decision to relocate has become so popular among companies in Germany, despite doubts about its economic efficiency, this paper draws on an analysis of German newspapers and business press published between January 1990 and July 2005, which was conducted by the author using Atlas.ti software for qualitative analysis.

The paper is organised as follows. The second section is an illustration of some of the theoretical assumptions about the role of ideas and isomorphic processes as they affect the change of interests in markets and the construction of myths. The third section emphasises the role of discourse in the processes of construction and diffusion of ideas and interests. 
The fourth section comprises the empirical analysis of the discourse on relocation in the German press between 1990 and 2005. The paper closes with concluding remarks.

\section{The Construction of Myths: Ideas and Isomorphic Processes as Drivers of Change in Interests and Organisational Behaviour}

We can translate the question of why companies decide to relocate their production to low-wage countries, and how this choice becomes a more general trend, into more theoretical terms: how entrepreneurs' interests are constituted and change and which processes might cause new strategies by actors to converge.

Since actors have to make sense of new strategies themselves, they must consider the strategies as appropriate and legitimate and interpret them as being in their own interests. In this process some strategies may become myths and framed 'in ways that resonate with [the] ideologies, identities and cultural understandings' of economic actors (Campbell 2005: 48). This emphasises the role of ideas in the construction of interests and the legitimation of new kinds of behaviours. Moreover, strategies have to be diffused in organisational fields. The more ideas are diffused, the more probable it is that strategies supporting such ideas become widespread. At the same time, the more these strategies are adopted or are perceived to be generally adopted by other actors, the more the ideas are reinforced. The diffusion of practices builds on framing as well as on the diffusion of information about the behaviour of other actors and the mobilisation of structural resources such as networks and power relationships. The diffusion of strategies supported by ideas takes place mainly as a result of isomorphic processes (DiMaggio \& Powell 1983).

\section{Framing Interests through Ideas}

Although economic interests might appear relatively stable in periods of economic stability, they cannot be considered as necessarily given a priori. Rather, they are the result of a social construction in which the diffusion of economic ideas plays an important role. Max Weber argued, in 'The Social Psychology of the World's Religions', that 'very frequently 'world images' that have been created by ideas have, like switchmen, determined the tracks along which action has been pushed by the dynamic of interests' (Weber [1922-23] 1961: 280).

How do ideas influence interests and behaviour? We can reasonably assume that interests are actors' 'wants' constructed on the basis of desires and beliefs (Blyth 2002). In addition, ideas can be distinguished in cognitive-cultural and normative constructs (Campbell 2004), where cognitive-cultural constructs such as paradigms presume theoretical cause-effect relationships, and normative constructs such as norms and values influence what is desirable. ${ }^{5}$ Ideas can thus influence actors' interests by becoming beliefs based on cause-effect relationships or normative guides.

Ideology and paradigms can also reduce uncertainty by making sense of the functioning of the economy for actors and defining their interests accordingly (Blyth 2002). They shape the legitimate ends of economic activities, as well as the means to reach those socially-approved ends (Jacobsen 1995). If, particularly under conditions of uncertainty, interests are not clear, ideas facilitate the choice of new strategies by altering the actors' definition of the economic situation and their beliefs about the consequences of their own actions (Blyth 2002). Ideas affect concrete individual behaviour because they influence the 
interpretation of reality and limit the range of options available for individuals (Denzau \& North 1994; North 1990).

Ideas may spark a change in interests, but they can also be used as post-facto justifications for new desires emerging from competitive or imitative, coercive or normative pressures. In both cases, whether they drive action or justify it, ideas are central to the construction of meaning and legitimation (Campbell 2004; Denzau \& North 1994). ${ }^{6}$

How much the ideas influence interests depends on the extent to which framing mechanisms take place. Frames can be defined as 'schemata of interpretation' that allow actors to perceive, identify and categorise events, define situations and make sense of the world (Goffmann 1974). As stated by Campbell (2005: 49), framing 'involves the strategic creation and manipulation of shared understandings and interpretations of the world, its problems and viable courses of action'. We already know that changes in interests can result from the use of ideas by institutional actors who face policy dilemmas in legitimising new policy choices or confront problems of a lack of legitimation (Campbell 2004; Goldstein \& Keohane 1993). Analogously, powerful market actors might want other companies further down the influence ladder to 'follow' their lead and adopt similar strategies. The more powerful actors would therefore promote ideas that would justify and legitimise this strategy adoption.

\section{The Diffusion of Interests and Strategies: The Role of Isomorphic Processes}

One location where processes of framing take place is in organisational fields. ${ }^{7}$ Such fields are imbued with cognitive and normative ideas (Fligstein 2001; Meyer \& Rowan 1991) and their structure manifests through networks, power relationships (Dobbin 2005; Fligstein 2001) or status hierarchies (Podolny 1993).

Myths are not only constructed by the diffusion of ideas; they are also constituted and reinforced through the increasing adoption of practices coherent with those ideas. In order to align actors' ideas, promote strategies coherent with such ideas and induce companies to adopt these strategies, it is also necessary to mobilise the market structure, i.e. to activate networks and make use of power relationships or status differences. DiMaggio and Powell (1983) have identified three kinds of mechanism of diffusion that presuppose forms of mobilisation of market structures. They correspond to three types of institutional isomorphism: coercive, normative and mimetic. The successful diffusion of new interests and strategies is more likely to occur if the backers of those new strategies are powerful, i.e. they form part of a hierarchy and are able to impose their will on their subordinates, they have high status and are thereby able to channel consensus towards particular norms of behaviour, or they have access to a wide social network that allows them to acquire and deliver information about the strategies of other actors. Institutional studies of organisations do not only identify mechanisms of myth-building in a field. They also point to some key actors who are particularly capable of mobilising the social structure - because they possess power, authority and wide network resources - and of aligning actors' interests and beliefs with the interpretive orientation and interests of power brokers (Meyer 2000; Snow et al. 1986; Tempel \& Walgenbach 2007). The distinction between the different kinds of isomorphism is mainly analytical. In reality, the diffusion of new kinds of organisational behaviour can be due to different types of isomorphic pressure that occur simultaneously.

Coercive isomorphism refers to the coercive regulation instigated by public institutions and private organisations (especially through contracts with more powerful organisations). 
In vertical relationships, powerful actors are able to give strong positive or negative economic incentives, sometimes even to coerce other dependent actors into particular types of behaviours. Powerful actors can use the media to provide principles for imposing new standards of behaviour and justifications on those companies that must adapt to these hierarchically-implemented requirements.

Normative isomorphism derives from professional expertise (e.g. among university specialists, consultants and professional organisations). For instance, academics operate in their own field. At the same time, they are connected to other fields from which they receive authority or even market opportunities. As 'spin doctors', well-connected professional experts can gain legitimation and authority, both personally and for their discipline or approach. And consultants are connected to industry since it represents part of their target market; they must adapt to the new demands and challenges that can be generated by larger companies or new sectors, and propose concrete solutions based on managerial ideas originally produced in academia (Blunsdon 2002; Kipping 1999). The more that economies of scale can be realised, as these solutions gain legitimation among a wider management audience, the more effective the diffusion can become. Legitimation for a particular business practice comes from face-to-face business relationships, reputation, and active use of the media. Experts and consultants can aid in the creation of fads and myths (Mazza \& Alvarez 2000) through this process of legitimation.

Mimetic isomorphism is particularly important under conditions of uncertainty. When acquiring information is particularly costly, market actors create cognitive categories and identify their actions with those of similar actors and key actors whom they consider as reference points (Barreto \& Baden-Fuller 2006). Information about the behaviour of the other actors is diffused through networks, and ideas can more easily be established, interpreted reflexively and disseminated widely (Campbell 2005; McAdam 1986; MacAdam $\&$ Scott 2005), making processes of imitation all the more probable: information about the behaviour of peers and particularly of high-status market actors can induce imitative processes through legitimation. In contrast to reputation, which builds on past behaviour, the notion of status is 'more directly tied to the pattern of relations and affiliations in which the actor does or does not choose to engage' (Podolny 2005: 13). This implies that, 'when an actor engages in behavior that can be interpreted by others as an exchange or association with another actor, the status of each affects the status of the other' (ibid.: 14). A status hierarchy is constructed not only by actors within the field, but also by external observers such as regulators and the media (Barreto \& Baden-Fuller 2006). These 'legitimacy providers' attribute a particular status according to their particular aims through deference attribution (Podolny 2005).

\section{The Role of Public Discourse}

There is general agreement in the literature that discourse is not merely a linguistic matter. It is intrinsically social, since it involves ideas, at titudes, social practices, power relationships and more (Fairclough 1989, 1995; Foucault 1972; Torfing 2005). It contributes substantially to the construction of reality and of regimes of truth (Lessa 2006).

To put it another way, public discourse is an arena where myths are built, i.e. where framing takes place and isomorphic processes are encouraged. As illustrated in Figure 1, discourse can help legitimise and justify new strategies, to frame them as interests according 


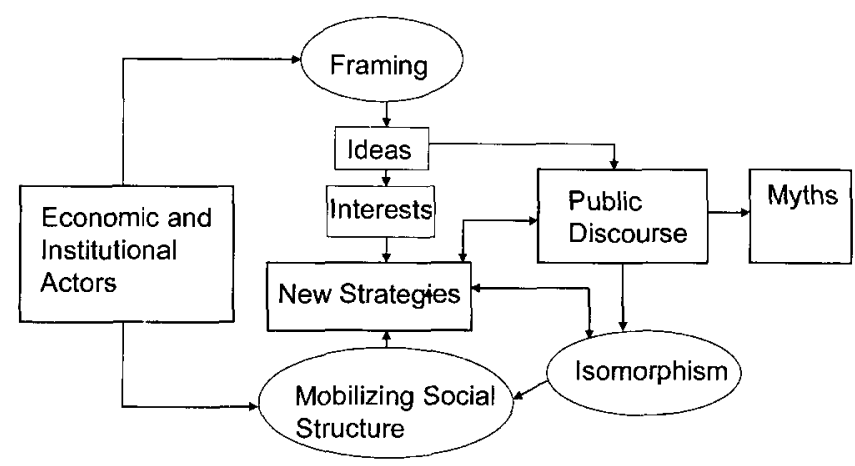

Fig. 1. Discourse and the process of myth-building.

to general ideas (Snow et al. 1986) or to make management theories and practices into concepts that the actors take for granted (Mazza \& Alvarez 2000). Through discourse, ideas and paradigms can be more or less strategically selected from a repertoire of possible assumptions about the functioning of the economy (Schmidt 2003). New options of behaviour legitimised by high-power and high-status actors can emerge and gain importance over other, older options.

Discourse often helps to make new types of behaviour ideationally legitimate and plausible, not only by presenting arguments in favour of those behaviours but also by delegitimising practices previously adopted and considered as appropriate. Some instances in which the delegitimising function of the discourse is evident are when previous or alternative behaviours are explicitly considered unattractive or doomed to failure; when their theoretical premises are judged to be inconsistent; or when the historical conditions for their success are no longer considered to be present.

Economic and institutional actors can also have a direct voice in the discourse through their active use of media relations. They may use these to package and frame interests into ideas, to make decisions and strategies appealing and legitimate according to their interests (Campbell 1998), or to interpret trends that they have also had a part in fostering. Actors can in fact activate other actors directly, for example through business relationships or by promoting their strategies in conferences, as well as by using the media to disseminate information on how their peers intend to behave and thereby helping to establish trends.

We can see how the analysis of public discourse helps to identify regimes of truth that influence actors' behaviours. Study of the public discourse can also deliver insights into processes of framing and the diffusion of strategies that take place through face-to face types of social mobilisation. ${ }^{8}$ It can highlight the strategies of actors involved in boosting isomorphic processes. Powerful actors, for instance, can push others to make particular decisions while providing public legitimation for those decisions at the same time.

Finally, there may be unintended consequences of the diffusion of ideology and information through discourse. Since mimetic processes do not seem to be selective, i.e. able to distinguish between 'good' and 'bad' choices (Barreto \& Baden-Fuller 2006), the diffusion of ideas and norms of behaviour through discourse can foster general patterns of behaviour independently of the empirical 'truth' of the ideas themselves. It could even be argued that decisions imposed hierarchically and justified in the public debate might become 
convenient for those in subordinate positions because of negative incentives, rather than because of the inherent advantages they would enjoy from those decisions. ${ }^{9}$

\section{Constructing the Myth of Cost Reduction through Relocation: The Discourse on Relocation in the German Press (1990-2005)}

The previous sections provided a theoretical framework to illustrate how interests and strategies change and become new myths in organisational fields. They also depicted the public discourse as an arena in which myths are built and key actors that are able to mobilise structural resources and induce isomorphic processes can frame and legitimise new strategies and thereby influence actors' interests and behaviours. Lastly, they emphasised that the development of dominant ideas in public discourse can produce unintended consequences and have possible negative effects on the new strategies adopted and their results.

The paper builds on the theoretical framework presented above in order to give an account of the initial empirical puzzle, i.e. why German companies have frequently opted to relocate production in recent years, despite the difficulties in producing efficiently offshore. The main hypothesis is that the interest in the business community to relocate, and the resulting trend in relocation, is based on overestimating the opportunities for cost reduction through relocation and underestimating the advantages of the home country as a base for production. We can find the reason for these misconceptions in the public discourse, which has built up the fundamental myth that relocation helps to consistently reduce costs over time, an advantage that apparently cannot be achieved in Germany any longer. The discourse has helped to frame the new strategy of shifting production locations by selecting, constructing and diffusing ideas, thereby redefining the situation of the German economy, instilling expectations about the benefits of relocation, providing information about the strategies of other actors and encouraging isomorphic processes. The myth of cost reduction through relocation is primarily built through the processes of framing and diffusion described above, as well as through the relocation decisions made largely uncritically by companies. The myth does not qualify how good the strategy of relocation is. If there is little mention of problems in the myth, however, and these concern crucial aspects of the companies' activities, then the myth can turn out to be a mystification and generate important unexpected consequences for companies. Turning to our case, if companies expect to reduce costs from relocation and that they will not have to address any further costs afterward, the efficiency of these firms will suffer and they will be unprepared for it. Consequences can be particularly hard for companies that cannot compensate for those unexpected costs through sufficiently high market benefits in the new environment.

The empirical analysis of the discourse in the German press that follows will illustrate the construction of the myth of cost reduction through relocation. Before dealing specifically with the discourse analysis on relocation and the position of the main actors in the discourse, however, we must examine the research method.

\section{Method}

The press analysis was conducted using the Atlas.ti software for qualitative analysis and is based on articles from German newspapers and the German business press archived into the LexisNexis database between January 1990 and July 2005. Some bias has to be allowed 
for because of the lack of homogeneity of the database. The LexisNexis database has in fact become increasingly richer over time, which of course does not permit a diachronic comparison, but it can be stated that at least since the mid-1990s, the database has become relatively homogeneous. I have decided to include all the articles selected for two reasons: first, there was a danger of losing information from a crucial time period. The beginning of the 1990 s is important because this is the time immediately after the fall of the Berlin Wall, which suddenly opened new investment perspectives outside the country for German companies. In addition, since the topic is less common in the press compared to other issues, a further selection would not have allowed enough material to be available to carry out the analysis.

The basic database includes 400 articles in total, selected on the basis of terms, combinations of terms or paraphrases related to the concept of 'relocation' (e.g. 'foreign direct investments' or 'FDIs', 'outsourcing', 'off-shoring', 'investments in foreign countries', 'internationalization' and 'industry').

The analysis was carried out on all kinds of articles, be they general reports by journalists, opinion articles or contributions by decision-makers. There was no distinction made between the different types of article. Although their impact on company decisions may vary (articles based on statements by economic actors can be assumed to have more influence on companies than, say, opinion articles), all kinds of articles can potentially contribute to defining the economic and institutional situation in Germany and in the target countries, identifying trends of company behaviour, discussing problems and providing solutions.

The actual discourse analysis consisted of three phases. The first phase involved selecting quotations line by line connected to relocation and coding them. The coding phase with Atlas.ti balanced deductive and inductive methods. An initial grid of possible dimensions connected to the main research questions was followed, but this grid had to be adjusted and enriched following the suggestions from the empirical material, i.e. the text of the articles. A total of 3429 quotations were obtained, of which 666 quotations could be attributed to specific actors (see below).

In order to analyse the actors' positions, all direct and indirect quotations by specific actors were coded with each actor's code and, where necessary, also with a content code. The analyses presented in Tables 1-5 and Figure 2 were conducted on all quotations on the topic selected. The analysis below is based on actors' quotations. Since the paper does not primarily focus on the media and its strategies, the descriptions of reality by journalists, claims and normative statements have only been quoted with a content code.

The second phase involved constructing family codes, i.e. codes situated at a higher level of abstraction than simple codes, according to semantic proximity and indicator relationship with the family code. The contrasted statements presented in Tables 1-5 are mainly family codes.

The third phase involved transforming the Atlas.ti database into an SPSS matrix to facilitate quantifying quotations and comparing the contrasting statements constituted by the family codes.

\section{The Messages in the Discourse on Relocation}

Since we have now established the influence of discourse on the processes of legitimation and the building of new myths, this section presents the main results of the analysis of public 
discourse in the German press. It illustrates how relocation trends and cost issues have been dealt with in general and gives particular attention to the role played by those economic and institutional actors who are considered to have the potential to induce isomorphic processes.

If we accept the theoretical assumptions illustrated in the previous sections, the public discourse in Germany has played an important role in the formation of expectations about the costs associated with relocations and in supporting relocation processes: (a) if relocation is presented as a popular and inevitable solution; (b) if the discourse discourages investing in the home country because of cost reasons and (c) builds on the rhetoric of cost reduction; (d) if relocation appears to have advantages or at least no contraindications for companies and for the home country, or if these are neglected or contentious; (e) if the rhetoric of cost-saving and its consequences is supported by general ideas and paradigms that become dominant in the discourse while competing ideas are neglected and, moreover, the public discourse encourages relocation practices; and ( $f$ ) if key economic and institutional actors or the group of peers support relocations and justify them by referring to the cost issue. Thus the discourse also supports or even encourages processes of isomorphism, reinforcing the myth. Finally, we can assume that the more ideas dominate the discourse, the more widespread we can expect uncritical relocation practices to be, i.e. if the discourses presents unilateral views of how the economy functions and neglects alternative opinions (see propositions (d) and (e) in particular).

Table 1 compares statements on relocation, particularly on its quantitative and qualitative aspects, in regards to proposition (a). The statements include quotations on the relocation trend and the intentions of entrepreneurs and managers in manufacturing and services to decentralise production internationally - through outsourcing, captive offshoring or greenfield investments. They also include quotations on whether the relocation trend is inevitable. The analysis shows clearly that the majority of quotations on the development of relocation present it as an increasing, sectorally expanding and inevitable trend. This is relevant because, in the public view, relocation becomes an almost 'natural' option. By giving information about the strategies adopted by other companies even if in a general way - the discourse on relocation can foster imitation processes (see also the second section). Relocation potentially becomes a self-fulfilling prophecy.

Such themes in the discourse are often connected to rhetoric that delegitimises the option to remain in Germany (proposition (b)) by giving a new interpretation of the German context and tacitly encouraging relocation. This rhetoric underlines the lack of competitiveness in Germany, where wages and non-wage labour costs, taxes and state regulation are all seen as being too high and politicians as unable to introduce the necessary

TABLE 1

Trend of relocations and their inevitability ( $\%$ of quotations on trends)

\begin{tabular}{lrr}
\hline & No. & $\%$ \\
\hline Relocation is growing and inevitable & 205 & 70.0 \\
Relocation is less frequent than imagined and not inevitable & 88 & 30.0 \\
Total & 293 & 100.0 \\
\hline
\end{tabular}

Source: Author's calculations (LexisNexis/Atlas.ti). 
reforms (Table 2). Yet quotations that ascribe the lack of company competitiveness to organisational inefficiencies or management errors are a small minority.

The accent on Germany's lack of competitiveness in the discourse on relocation is stronger in the press than the emphasis placed on the advantages of target countries to which German companies relocate, including cost advantages (Table 3).Indeed, the advantages of investing in low labour-cost countries are indirectly derived from the perceived disadvantages of remaining in Germany.

The discourse on relocation is constructed around the rhetoric of cost reduction as well as the possible neglect of further unexpected and non-calculable costs associated with the processes of internationalisation through relocation (proposition (c)). As Figure 2 shows, almost 70 per cent of the quotations on the reasons for relocation transmit the idea that moving production contributes to cutting costs, whether these are taxation costs, wage or non-wage labour costs, bureaucracy costs, or other. Only about one-quarter of the quotations on relocation motives underline the point that relocation helps in acquiring new markets. A minority of quotations present the idea that relocation is connected to general processes of internationalisation on the part of big companies and therefore their suppliers as well. The discourse in the general and business press on relocation thus focuses more on cutting costs than on the argument that relocation contributes to the economic expansion of German companies.

The focus of the press discourse on relocation is on the reduction of calculable costs, however. The number of quotations signifying that relocation cuts costs is clearly higher than the number of quotations that deem relocation to (also) have hidden costs (Table 4). Hidden costs are associated with the management of intercultural differences, organisation

\section{TABLE 2}

German competitiveness versus stagnation

\begin{tabular}{lrr}
\hline & No. & $\%$ \\
\hline Germany is still competitive & 79 & 33.8 \\
Germany is no longer competitive & 152 & 65.0 \\
German companies are no longer competitive & 3 & 1.3 \\
Total & 234 & 100.0 \\
\hline
\end{tabular}

Source: Author's calculations (LexisNexis/Atlas.ti).

TABLE 3

German competitiveness versus advantages of target countries

\begin{tabular}{lrr}
\hline & No. & \multicolumn{1}{c}{$\%$} \\
\hline Target countries are particularly attractive & 85 & 32.4 \\
Target countries are attractive under certain conditions & 25 & 9.5 \\
Germany is no longer competitive & 152 & 58.0 \\
Total & 262 & 100.0 \\
\hline
\end{tabular}

Source: Author's calculations (LexisNexis/Atlas.ti). 


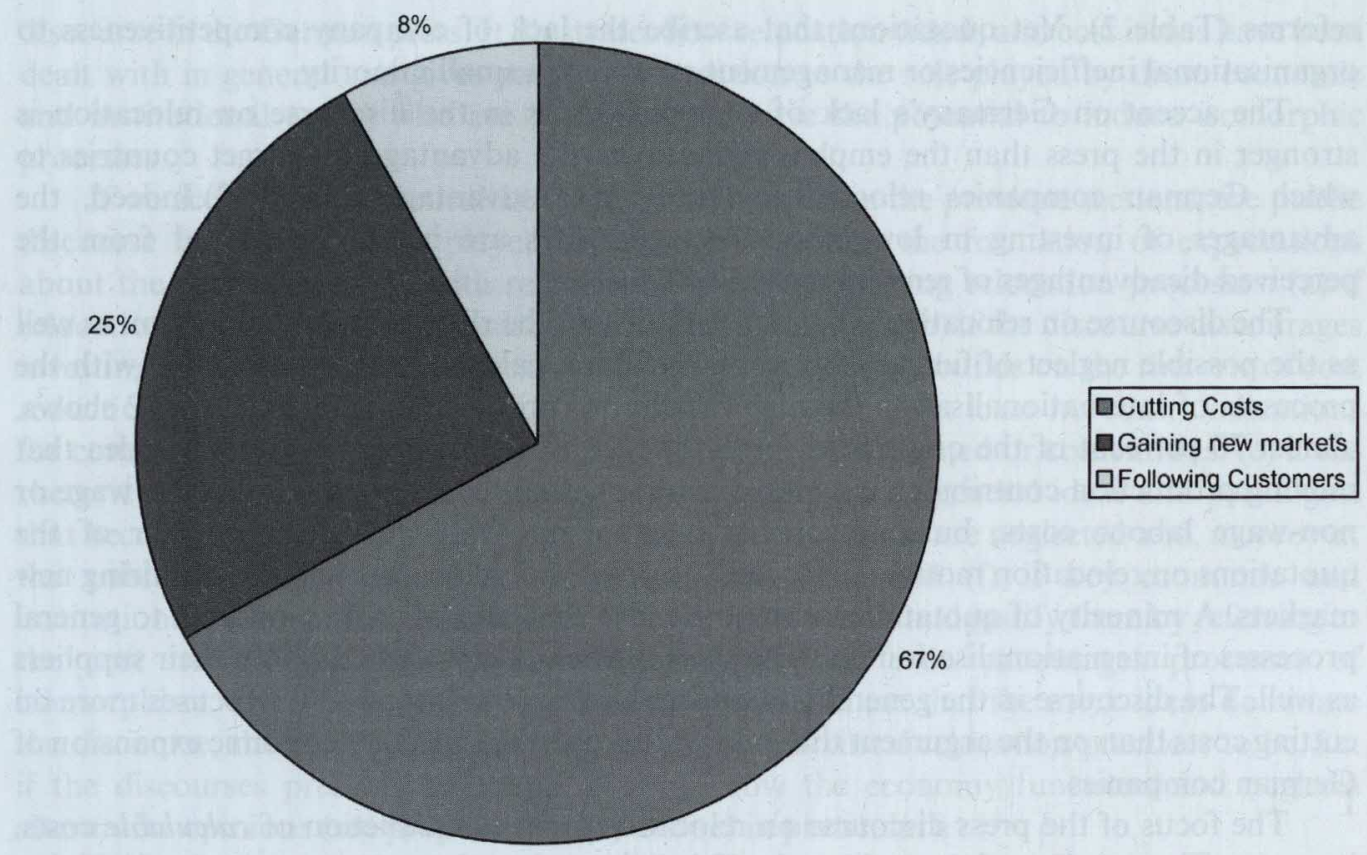

Source: Author's calculations (LexisNexis/Atlas.ti).

Fig. 2. Discourse on relocation focused on cutting (calculable) costs ( $\%$ of quotations on relocation motives).

problems (related to logistics, productivity, maintenance of quality standards, the need for further expertise), the lack of a skilled labour force, the danger of know-how transfer and the indirect support of potential competitors. The statement 'relocation has hidden costs' also includes statements such as 'the risks of relocation are not well considered', 'the benefits of relocation are less than expected' or 'the benefits of relocation will be reduced in the medium to long run'. Even the reference to the costs of relocation does not really have the function of inviting the decision-makers in the companies to make more reflective decisions. Instead, it is often used instrumentally by consultants to emphasise that firms need (their) expertise if they want to relocate production.

So far we have seen that practices of relocation can increase if they are presented to and perceived by entrepreneurs and managers as something inevitable and gaining in importance. They can also increase if the disadvantages of the home country are emphasised, if relocation is presented as a simple solution to these disadvantages and if pro-relocation arguments are selected and alternative arguments are neglected. In order for 


\section{TABLE 4}

Cutting costs versus hidden costs associated with relocation $(\%$ of quotations on relocation and costs)

\begin{tabular}{llr}
\hline & No. & $\%$ \\
\hline Relocation cuts costs & 379 & 60.1 \\
Relocation has hidden costs & 252 & 39.9 \\
Total & 631 & 100.0 \\
\hline
\end{tabular}

Source: Author's calculations (LexisNexis/Atlas.ti).

TABLE 5

Effects of relocation on the home country ( $\%$ of quotations on effects)

\begin{tabular}{llr}
\hline & No. & $\%$ \\
\hline Relocation negatively affects the home country & 120 & 48.2 \\
Relocation benefits home country or has no effect & 129 & 51.8 \\
Total & 249 & 100.0 \\
\hline
\end{tabular}

Source: Author's calculations (LexisNexis/Atlas.ti).

actual relocation processes to be encouraged, however, it is important that the discourse on relocation also emphasises the positive effects of relocation or at least implies that there are no explicit contra-indications (proposition (d)). In fact, we could argue that if the actual performance of subsidiaries abroad is simply ignored in the discourse, this too would foster relocation. Actors might just deduce good performance from what dominant ideas and paradigms would predict, or by the mere fact that most companies are assumed to be acting that way.

The discourse in the German press is not explicit at all when discussing the fates of those companies that decide to relocate. Achievement is often related to the relocation processes themselves or to companies' predictions about future gains from relocation. The discourse neglects the actual outcomes measured with hard indicators and associated with relocation strategies.

The issue is quite contentious when it comes to the general effects for the home country. Like other unpopular decisions based on particularistic interests, the decision to relocate also needs to be justified with reference to the common good. From this point of view, it is interesting to compare the statements about the effects that relocation has on Germany (Table 5).

The negative effects of relocation on developed countries easily come to mind: higher unemployment and reduction of foreign direct investment, know-how transfer, brain drain, etc. At the company level, this primarily means downsising (Ahlers et al. 2007; Berger 2006). However, the statements that emphasise the negative consequences of relocation account only for a minority of the quotations on this issue. Relocation is mainly considered to be neutral or even advantageous for the home country (Deutsche Bundesbank 2006). This 
position in the discourse reflects the economic idea of globalisation as a win-win situation. While the globalisation of markets produces a transfer of low-skilled labour to low-wage countries, it encourages the growth of high-skilled employment in the home country (Ricardo [1817] 1821; Samuelson 2004). Moreover, with production being in low-wage countries, consumers can profit from lower prices. Finally, since the goal of relocation is the acquisition of new markets, this can only have positive effects for the headquarters. One consequence is that companies that wish to relocate their production can rely on a strong position that supports their choices and offers few moral doubts.

The redefinition of the economic situation in Germany - in particular, the statements on the lack of competitiveness of the German economic system, calling it too expensive, the emphasis on prescriptions for deregulation and cost-saving through investments in low-wage countries, and the accent on the advantages that relocating brings to the German economy - has largely justified and framed the strategy of relocation in terms of neoliberal idea ${ }^{10}$ and the classical Ricardian theory of international trade and competitive advantage of nations (proposition (d)). The use of experts, particularly economists, is additional evidence of a connection to ideas and paradigms, and will be dealt with in more detail in the next section.

\section{The Actors in the Discourse on Relocation}

Discourse has the potential to leave room for different ideas, paradigms and legitimations of action to prevail. But which discourse becomes dominant and which strategies become widespread among market actors depends strongly on the protagonists, i.e. on those key actors that 'create,' and in some cases even manipulate, the discourse. We can assume that the myth of cost reduction through relocation is being created and reinforced if the main actors in the discourse on relocation are also those who usually account for inducing isomorphic processes (proposition (f)).

The diffusion of neoliberal ideas and of relocation practices is no mere coincidence, as is quickly evident if we consider the main actors who have a voice in the press, and the way that these actors use the press strategically to frame new strategies for companies that align with the actors' own interests. Figure 3 shows the direct quotations identified in the press, broken down according to actors.

Generally speaking, the ability to change an economic actor's interests often requires the presence of lead actors and actors in the peer group in general who can introduce changes first and support them publicly in the press and elsewhere. Entrepreneurs and managers play an important role in the debate: in fact, as shown in Figure 3, they have the leading voice among the actors involved. An analysis of their positions in the debate is important, because if entrepreneurs and managers are to change their attitudes and preferences, the voices of their peers are much more credible than those of other actors would be. Moreover, this enables us to observe how high-power companies construct ideas and provide justifications in the press for coercive behaviour.

According to our analysis of the press, around 65.2 per cent of the entrepreneurs/ managers' quotations consider relocation a positive thing. However, the positive attitude towards relocation does not necessarily rely on experience and actual performance indicators. When cases of companies' relocations are covered in the press, the stories tell of the intentions to relocate, of new investments abroad just completed, of forecasts about future market opportunities. This push toward imitation processes in companies is based 


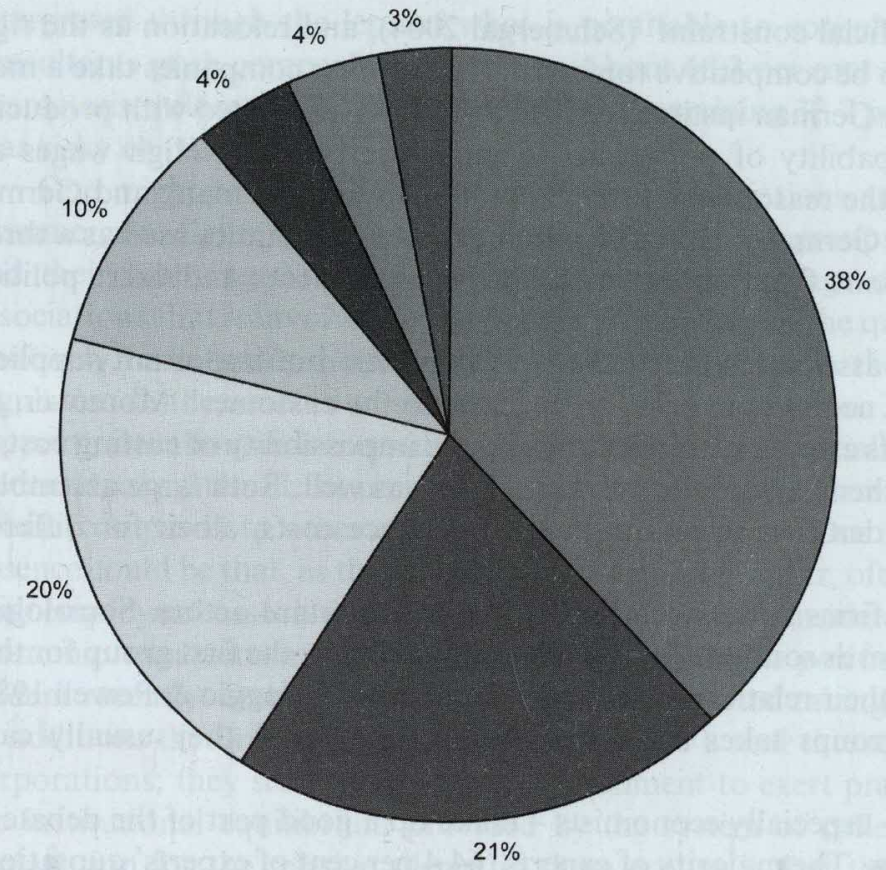

\begin{tabular}{|l|}
$\square$ Entrepreneurs/Managers \\
$\square$ Consultants \\
$\square$ Economists \\
$\square$ Employers'associations \\
$\square$ Unions \\
$\square$ Politicians/Government \\
$\square$ Chambers \\
\hline
\end{tabular}

Source: Author's calculations (LexisNexis/Atlas.ti).

Fig. 3. Actor presence in the German press on the issue of relocation ( $\%$ of quotations by groups of actors).

more on chimeras than on empirical evidence. The remaining 34.8 per cent of the quotations express doubts about the success of relocation or are in favour of keeping production in the home country. This last position receives particular support from mid-sized family enterprises that produce high-quality products and are deeply regionally embedded. These relocation detractors make explicit use of identity-based arguments such as tradition particularly family tradition - and patriotism to foster commitment to their region and to Germany, hence the decision to stay.

High-powered German companies are ever-present in the press, even if not with the same frequency, and their criticism of their home country differs. In any case, the cost issue seems to be central, judging from most company statements. Large assemblers seem to be actually coercing suppliers into moving to new business locations, using strategies that have been effectively summarised as 'Out of Germany or out of business!' (Handschuch 2004). Some of the bigger German firms consider their own investments in plants abroad to be a direct consequence of cost pressure due to globalisation, and frame such investments as an expression of the long-term perspective of the company. Globalisation is in this sense 
presented as a sort of 'beneficial constraint' (Schmergal 2004), and relocation as the right thing to do today in order to be competitive tomorrow. Some other companies take a more critical position towards the German institutions, the high costs associated with producing in Germany, and the incapability of politicians to introduce reforms. High wages are generally considered to be 'the reason why foreign investors avoid Germany and German investors turn their back on Germany' (LZ 2003). Relocation is sometimes used as a threat in order to obtain concessions from unions in collective agreements and exert political pressure for reforms.

The discourse of large assemblers is reflected in the position of important suppliers. These define relocation as a necessity in order to be 'close to the customer'. Moreover, the tremendous pressure on costs exerted hierarchically and the impossibility of cutting costs in Germany are said to force them to look for other locations as well. Both large assemblers and suppliers support the idea that relocation helps to reduce costs, albeit for different reasons.

Academics, consulting firms and associations are also important actors. Sociological organisation theory sees them as sources of normative isomorphism: the first group for their expertise, the latter two for their relationships to entrepreneurs (DiMaggio \& Powell 1983). Note that none of these groups takes a neutral position, however; they usually carry ideological and interest bias.

The academic experts - especially economists - make up a good part of the debate on relocation, as Figure 3 shows. The majority of experts (64.4 per cent of experts' quotations) describe relocation as the inevitable expression of the importance of market principles and competition: companies buy where the prices for raw materials and semi-manufactured products are lower, and they go where there is potential for labour-cost advantages and gaining market share. The experts claim that competition over price implies the need for reforms to reduce the role of the state in the home country, and provide the ideological foundation as well as the scientific legitimation for relocation. The rest of the experts (35.6 per cent of quotations) consider relocation to be less inevitable and more problematic, especially for less standardised kinds of production. The competitiveness of a country should not only be measured by wage costs; productivity should also be taken into account. This minority of experts sees relocation as more of a threat than an advantage to the home country.

Consulting firms have a special place in the debate. They are actors with an interest in increasing relocation processes, since they depend on the companies who use consultants as a source of relocation expertise. Consultants have used the press systematically to develop their business: it is not uncommon, in fact, for articles on relocation to be written around the results of surveys produced by consulting firms or on the basis of interviews with consultants. In about 30 per cent of the articles in which consultants are quoted, the name of the consulting firm receives extra emphasis in the subheading of the article and in the contact details at the end. In some cases, the authors of the articles are themselves consultants.

The position of the consultants is a bit different from that of the economists. Consultants generally underline the inevitability of relocation processes and present findings from company studies that demonstrate the intention to relocate. But they also underline some risks and costs to which entrepreneurs and managers must give adequate consideration when deciding to relocate, and which can be minimised by effective consulting. Some of the quotations on the costs of relocation mentioned above should be 
interpreted through the lens of what is profitable to consultants. All things considered, consultants push companies to relocate. About 66.3 per cent of quotations by consultants characterise relocation positively, in fact; the remaining 33.7 per cent of quotations identify it as risky or problematic.

One might reasonably expect employers' associations and the German Chamber of Commerce to figure more in the media because of both groups' relationships to companies and their lobbying function. But of the small percentage of chambers and employers' associations that is involved in the debate, 69 per cent of the quotations describe relocation positively, as a natural option for companies to escape the burdens of German state regulation in the absence of specific policies of deregulation. This shows that associations support relocation as an institutionalised practice by essentially delegitimising the German institutional system. Like unions, employers' associations are generally less present in the debate compared to other actors, at least in the press. One explanation for this general absence could be that, as the main representatives of bigger, often multinational companies, both employers' associations and unions have mainly considered relocation as a strategy of economic expansion rather than a zero-sum game, a position which has become more evident recently. Only in recent years have they started taking positions in the press at all. In addition, the unions do not see relocation as a real threat to German employment in corporations; they see it instead as an instrument to exert pressure on the unions to alter the institutional equilibrium provided by the system of collective agreements. A second explanation for the relative silence in these groups is that the supporters of deregulation consider unions and employers' associations - main actors in the system of industrial relations - as a part of the world that the German economy should distance itself from. This aspect is particularly evident if we consider that most of the debate has taken place in business magazines and the more conservative press rather than in the left-wing press. The analysis of the actors in the press underlines the presence of a relatively dominant set of actors that are pushing relocation strategies, while a competing position, for instance one supported by unions, is lacking.

\section{Concluding Remarks}

This paper highlights the puzzle in current relocation studies and attempts to explain it. While relocation has become an important and popular step for German companies, the studies on relocation point to its unexpected costs and widespread inefficiencies, drawbacks that can even lead to investment failure. In order to explain this puzzle and particularly to explain the discrepancy between the expectations and actual experience of relocation, we must consider the influence of the diffusion of dominant ideas along with the isomorphic processes that are encouraged by the public discourse.

The diffusion of relocation strategies is not based on interests given a priori. Instead, it implies general changes at the cognitive level and is the result of myth-building that comes from a diffusion of ideas. These ideas frame interests and expectations and can make changes conceivable, plausible and legitimate. Yet the changes may actually result from a deliberate use of ideas by institutional actors in order to promote cooperation and processes of imitation in the field. What's more, dominant ideas based on simplistic representations of reality can lead to false expectations, and hence to decisions that reveal themselves to be inefficient and costly. 
An analysis of the discourse can help to explain the puzzle, especially the reasons why there is a gap between expectations and reality in relocation processes. This paper has therefore investigated the way the German discourse since the 1990s has presented the phenomenon of the internationalisation of production, with particular attention to the perceived relocation trend, the costs associated with relocation and the use of economic ideas to legitimise relocation and to make it into something plausible. The German discourse is in fact focused on the idea that relocation is increasing and inevitable, that relocation leads to cost reductions without any additional friction, and strongly underlines these thoughts with references to neoliberal ideas and theories of international trade. At the same time, the advantages of relocating as covered in the press are mostly derived from the weaknesses of the German model, rather than from any positive picture of the destination country concerned. Moreover, the discourse neglects to mention possible costs; it presents relocation practices in a positive light without providing any indicators of actual performance gains after relocation, thereby encouraging the uncritical imitation of these practices.

This particular discourse, which is mainly based on the rhetoric of costs, prevails in part because of the constellation of the main actors in the discourse, particularly companies, economic experts and consultants. These actors have power, status and the capacity to mobilise structural resources, all of which they can wield to bring about widespread organisational changes in their fields and, through the use of the public discourse, provide ideal justification for these changes at the same time.

Far from discouraging relocation tout court, this paper was an attempt to look at phenomena of relocation more critically than the literature and the discourse itself have done so far. The paper's emphasis on the social processes and constellations of interests behind the diffusion of new management strategies, along with the theoretical bias that lies behind the claims of economic efficiency through relocation and the exhortations to relocate, is a warning against the dangers of uncritical decision making about relocations. It is an urgent call to seriously consider the costs of relocation.

\section{Acknowledgements}

I am very grateful to Kathrin Woltering for her support in conducting the press analysis and to Patrick Aspers, Nina Bandelj, Jack Barbalet, Jens Beckert, Brooke Harrington and Akos Rona-Tas for their useful comments and suggestions regarding previous versions of the paper. Special thanks to the anonymous referees for their very helpful review.

\section{Notes}

1 The term 'relocation' is used as a translation of the term 'Standortverlagerung,' which is normally used in the German literature and press. Although this term recalls those investments in production plants that imply a transfer of production activities from one location to another as a sort of zero-sum game, the current use of 'Standortverlagerung' includes all forms of internationalisation of production.

2 According to a survey carried out by the Fraunhofer Institut on a representative sample of German firms, in 200646 per cent of offshoring manufacturing companies were large (500 or more employees), 22 per cent were medium-sized (100-499 employees) and 10 per cent were small (20-99) enterprises (Kinkel and Maloca 2008). 
3 These two aims tend to coexist when companies decide to relocate. Therefore, it is possible that the higher costs can be balanced by higher sales volumes. However, in this paper I will only focus on the question of costs that can jeopardise or at least reduce the profitability of a company, especially if the company in question has difficulties in entering foreign markets and adapting to them.

4 While from 2004 to 2006 about 55 per cent of relocations were to the new European member states, 39 per cent of all companies that came back to Germany in the same period of time were withdrawing from these countries (Kinkel and Maloca 2008).

5 Goldstein and Keohane (1993) offer a more detailed distinction between types of ideas: principal beliefs consist of the set of norms that influence interests; causal beliefs are based on theoretical cause-effect relationships; and worldviews refer to the cultural repertoire of actors. Paradigms are generally constituted by complex sets of cause-effect relationships but might be based on or go against normative principles. Causal beliefs can also become the basis for more general world views.

6 New interests presume, or are accompanied by, a change at the cognitive level. However, since action also depends on other conditions that facilitate or constrain the coherent realisation of interests (for example, financial capabilities, where entrepreneurs are concerned), not all interest changes - i.e. not all new ideas, paradigms and world views - translate into coherent action. The adoption of new ideas and the changes in interests are therefore necessary conditions for intentions of action and action itself, but they are not sufficient ones alone.

7 Framing also takes place in public opinion, as will become clear in the next section.

8 Although framing and isomorphic processes are separated analytically here, they act jointly and reinforce each other. Processes of imitation in particular (mimetic isomorphism) are supposed to become stronger as ideas are diffused more widely; at the same time, the diffusion of ideas may depend on the activation of networks (Campbell 2005; McAdam 1986; MacAdam and Scott 2005) and power relationships.

9 For instance, automobile industry suppliers were compelled to follow large assemblers to China so that the MNCs there could fulfill the local content conditions imposed by the Chinese government and guarantee certain quality standards in production, but this was a situation in which market size was still very small and where the costs of investment and production would not balance for a long time.

10 For recent overviews of neoliberalism and its principles, see Campbell and Pedersen (2001) and Mudge (2008). On the diffusion of neoliberalism, see Plehwe et al. (2006). On the neoliberal view of globalisation and relocation trends in Germany, see Sinn (2005).

\section{References}

Ahlers, E., Öz, F. and Ziegler, A. (2007) Standortverlagerung in Deutschland: Einige empirische und politische Befunde (Düsseldorf: Hans-Böckler-Stiftung).

Barreto, I. and Baden-Fuller, C. (2006) to conform or to perform? Mimetic behaviour, legitimacy-based groups and performance consequences, Journal of Management Studies, 47(7): $1559-1581$.

Beckert, J. (1996) What is sociological about economic sociology?, Theory and Society, 25: 803-840.

Beckert, J. (1999) Agency, entrepreneurs and institutional change, Organization Studies, 20(5): $777-799$.

Beckert, J. (2002) Beyond the Market: The Social Foundations of Economic Efficiency (Princeton: Princeton University Press).

Berger, S. (1996) Introduction, in: S. Berger and R. Dore (eds), National Diversity and Global Capitalism (Ithaca: Cornell University Press), pp. 1-25.

Berger, S. (2006) How We Compete: What Companies Around the World are Doing to Make it in Today's Global Economy (New York: Doubleday). 
Blunsdon, B.J. (2002) Beneath Fashion: Why is There a Market for Management Consulting Services? (Alberta: University of Alberta).

Blyth, M. (2002) Great Transformations: Economic Ideas and Institutional Change in the Twentieth Century (Cambridge: Cambridge University Press).

Campbell, J.L. (1998) Institutional analysis and the role of ideas in political economy, Theory and Society, 27: 377-409.

Campbell, J.L. (2004) Institutional Change and Globalization (Princeton and Oxford: Princeton University Press).

Campbell, J.L. (2005) Where do we stand? Common mechanisms in organizations and social movements research, in G. F. Davis et al. (eds), Social Movements and Organization Theory (Cambridge: Cambridge University Press), pp. 41-68.

Campbell, J.L. and Pedersen, O.K. (eds) (2001) Neoliberalism and Institutional Analysis (Princeton: Princeton University Press).

Castells, M. (2000) Materials for an exploratory theory of the network society, British Journal of Sociology, 51(1): 5-24.

Crouch, C. and Streeck, W. (1997) Introduction: The future of capitalist diversity, in C. Crouch and W. Streeck (eds), Political Economy of Modern Capitalism: Mapping Convergence and Diversity (London: Sage), pp. 1-18.

Culpepper, P.D. (2003) Creating Cooperation: How States Develop Human Capital in Europe (Ithaca and London: Cornell University Press).

Denzau, A. and North, D.C. (1994) Shared mental models: ideologies and institutions, Kyklos, 47(1): $3-31$.

Deutsche Bank (2004) Deutsche Investitionen in China: Chance für Deutsche Unternehmen? China Spezial (Deutsche Bank Research).

Deutsche Bundesbank (2006) Die deutschen Direktinvestitionsbeziehungen mit dem Ausland: neuer Entwicklungstendenzen und makroökonomische Auswirkungen (Frankfurt am Main: Deutsche Bundesbank).

DIHK (2003) Produktionsverlagerung als Element der Globalisierungsstrategie von Unternehmen. Ergebnisse einer Unternehmensbefragung (Berlin: Deutsche Industrie und Handelskammer).

DIHK (2006) Investitionen im Ausland. Ergebnisse einer DIHK: Umfrage bei den Industrie- und Handelskammern Frühjahr 2006 (Berlin: Deutsche Industrie und Handelskammer).

DiMaggio, P.J. and Powell, W.A.W. (1983) The iron cage revisited: institutional isomorphism and collective rationality in organizational fields, American Sociological Review, (48): 147-160.

Dobbin, F. (2005) Comparative and historical approaches to economic sociology, in N. J. Smelser and R. Swedberg (eds), The Handbook of Economic Sociology, second edition (Princeton: Sage).

Dunning, J.H. (1993) The Globalization of Business (London: Routledge).

European Commission (2003) Internationalisierung von $K M U$, Beobachtungsnetz der europäischen KMU.

Fairclough, N. (1989) Language and Power (Harlow: Longman).

Fairclough, N. (1995) Critical Discourse Analysis (Harlow: Longman).

Faini, R. (2004) Trade Liberalization in a Globalizing World (Bonn: IZA).

Fligstein, N. (2001) The Architecture of Markets: An Economic Sociology of Twenty-first-century Capitalist Societies (Princeton: Princeton University Press).

Foucault, M. (1972) Archeology of Knowledge (New York: Pantheon).

GIC and EAC (2008) German Business Expansions in China 2008-2010: Results of Survey among German Operations in China on Market Potential, Business Barriers and Future Business Outlook (Shanghai: German Chamber of Commerce).

Goffmann, E. (1974) Frame Analysis: An Essay on the Organization of Experience (New York: Harper \& Row).

Goldstein, J. and Keohane, R.O. (1993) Ideas and foreign policy: an analytical framework, in J. Goldstein and R. O. Keohane (eds), Ideas and Foreign Policy: Beliefs, Institutions, and Political Change (Ithaca and London: Cornell University Press), pp. 3--30. 
Hall, J.A. (1993) Ideas and social sciences, in J. Goldstein and R. O. Keohane (eds), Ideas and Foreign Policy: Beliefs, Institutions, and Political Change (Ithaca and London: Cornell University Press), pp. 31-54.

Hall, P.A. and Soskice, D. (2001) An introduction to varieties of capitalism, in P. A. Hall and D. Soskice (eds), Varieties of Capitalism: The Institutional Foundations of Comparative Advantage (Oxford: Oxford University Press), pp. 1-68.

Handschuch, K. (2004) EU-Osterweiterung out of Germany, Wirtschaftswoche, 10 March.

Hardock, P. (2000) Produktionsverlagerung von Industrieunternehmen ins Ausland: Formen, Determinanten, Wirkung (Wiesbaden: Gabler).

Hirsch-Kreinsen, H. and Schulte, A. (2000) Einführung: Standortentscheidungen zwischen Globalisierung und Regionalisierung, in H. Hirsch-Kreinsen and A. Schulte (eds), Standortbindungen: Unternehmen zwischen Globalisierung und Regionalisierung (Berlin: Edition Sigma), pp. 9-28.

Iida, K. (1993) Analytic uncertainty and international cooperation: theory and application to international economic policy coordination, International Studies Quarterly, 37(4): 431-457.

Jacobsen, J.K. (1995) Review: Much ado about ideas: the cognitive factor in economic policy, World Politics, 47(2): 283-310.

Kinkel, S. and Maloca, S. (2008) Produktionsverlagerungen rückläufig: Ausmaß und Motive von Produktionsverlagerungen und Rückverlagerungen im deutschen verarbeitenden Gewerbe (Fraunhofer Institut System und Innovationsforschung), Mitteilungen aus der ISI-Erhebung zur Modernisierung der Produktion, n. 45.

Kinkel, S., Lay, G. and Maloca, S. (2004) Produktionsverlagerungen ins Ausland und Rückverlagerungen (Karlsruhe: Fraunhofer Institut Systemtechnik und Innovationsforschung), Paper 8/04.

Kipping, M. (1999) American management consulting companies in Western Europe, 1920 to 1990: products, reputation, and relationships, Business History Review, 73(2): 190-220.

Lessa, I. (2006) Discursive struggles within social welfare: restaging teen motherhood, British Journal of Social Work, 36(2): 283-298.

LZ (2003) Noch nicht war die Chance für Strukturreform größer: Interview mit Bernd A. Stecher, Chef Volkswirt der Siemens AG, Börsen-Zeitung, 17 July.

MacAdam, D. and Scott, R.W. (2005) Organizations and movements, in G. F. Davis et al. (eds), Social Movements and Organization Theory (Cambridge: Cambridge University Press), pp. 440.

Mazza, C. and Alvarez, J.L. (2000) Haute couture and prêt-à-porter: the popular press and the diffusion of management practices, Organization Studies, 21(3): 567-588.

McAdam, D. (1986) Recruitment of high-risk activism: the case of Freedom Summer, American Journal of Sociology, 92(1): 64-90.

Meck, G. (2007) Deutsche Konzerne überschätzen China, Frankfurter Allgemeine Zeitung,.

Meyer, J.W. (2000) Globalization: sources and effects on national states and societies, International Sociology, 15(2): 233-248.

Meyer, J.W. and Rowan, B. (1991) Institutionalized organizations: formal structure as myth and ceremony, in W. M. Powell and P. J. DiMaggio (eds), Institutionalism in Organizational Analysis (Chicago: University of Chicago Press), pp. 41-62.

Mudge, S.L. (2008) The state of the art: what is neo-liberalism?, Socio-Economic Review, 6: 703-731.

North, D.C. (1990) Institutions, Institutional Change and Economic Performance (Cambridge: Cambridge University Press).

OECD (2004) Trends and Recent Developments in Foreign Direct Investment (Paris: OECD).

Plehwe, D., Walpen, B. and Neunhöffer, G. (eds) (2006) Neoliberal Hegemony: A Global Critique (London: Routledge).

Podolny, J.M. (1993) A status-based model of market competition, American Journal of Sociology, 98(4): 829-872. 
Podolny, J.M. (2005) Status Signals: A Sociological Study of Market Competition (Princeton: Princeton University Press).

Ricardo, D. [1817] (1821) On the Principle of Political Economy and Taxation (London: John Murray).

Samuelson, P.S. (2004) Where Ricardo and Mill rebut and confirm arguments of mainstream economists supporting globalization, Journal of Economic Perspectives, 18(3): 135-146.

Schmargal, C. (2004) Rette sich wer noch kann, Welt am Sonntag, 28 March.

Schmidt, V.A. (2003) The boundaries of 'bounded generalizations': discourse as the missing factor in actor-centred institutionalism, in R. Maintz and W. Streeck (eds), Die Reformbarkeit der Demokratie (Frankfurt am Main: Campus Verlag), pp. 318-350.

Schulte, A. (2002) Das Phänomen der Rückverlagerung: Internationale Standortentscheidungen kleiner und mittlerer Unternehmen (Wisebaden: Gabler).

Sinn, H.-W. (2005) Die Basar-Ökonomie. Deutschland: Exportweltmeister oder Schlußlicht? (Berlin: Econ).

Snow, D.A. et al. (1986) Frame alignment processes, micromobilization, and the movement participation, American Sociological Review, 51(4): 464-481.

Statistisches Bundesamt (2008) Verlagerung wirtschaftlicher Aktivitäten (Wiesbaden: Statistisches Bundesamt.

Tempel, A. and Walgenbach, P. (2007) Global standardization of organizational forms and management practices? What new institutionalism and the business-systems approach can learn from each other, Journal of Management Studies, 44(1): 1-24.

Torfing, J. (2005) Discourse theory: achievements, arguments and challenges, in D. Howarth and J. Torfing (eds), Discourse Theory in European Politics (New York: Palgrave), pp. 1-32.

Weber, M. ([1922-23] 1961) Social psychology of the world's religions, in H. H. Gerth and C. M. Mills (eds), From Max Weber: Essays in Sociology (New York: Oxford University Press). 